\title{
Diversity of Ralstonia pseudosolanacearum, the causal agent of bacterial wilt on Eucalyptus pellita in Indonesia
}

\author{
BAYO ALHUSAERI SIREGAR ${ }^{1}$, GIYANTO ${ }^{1, \boldsymbol{v}}$, SRI HENDRATUTI HIDAYAT ${ }^{1}$, \\ ISKANDAR ZULKARNAIN SIREGAR ${ }^{2}$, BUDI TJAHJONO ${ }^{3}$ \\ ${ }^{1}$ Department of Plant Protection, Faculty of Agriculture, Institut Pertanian Bogor. Jl. Kamper, Kampus IPB Darmaga, Dramaga, Bogor 16680, West Java, \\ Indonesia. Tel.: +62-251-8629354, Fax.: +62-251-8629352, ‘email: giyanto@ apps.ipb.ac.id \\ ${ }^{2}$ Department of Silviculture, Faculty of Agriculture, Institut Pertanian Bogor. Jl. Kamper, Kampus IPB Darmaga, Dramaga, Bogor 16680, West Java, \\ Indonesia \\ ${ }^{3}$ R\&D Division, PT. Arara Abadi, Sinarmas Forestry. Jl Minas-Perawang Km. 26, Perawang 28772, Riau, Indonesia
}

Manuscript received: 6 May 2021. Revision accepted: 31 May 2021

\begin{abstract}
Siregar BA, Giyanto, Hidayat SH, Siregar IZ, Tjahjono B. 2021. Diversity of Ralstonia pseudosolanacearum, the causal agent of bacterial wilt on Eucalyptus pellita in Indonesia. Biodiversitas 22: 2538-2545. The Ralstonia species complex was initially classified into five races and five biovars but the classification could not accommodate the isolates' phylogenetic history or geographic origins. A phylotype and sequevar system is based on the geographic distribution and characteristics of endoglucanase (egl) and hypersensitive response and pathogenicity ( $h r p)$ gene sequences. This study aims to describe pathogen diversity of the causal agent of bacterial wilt on Eucalyptus pellita F. Muell. Pathogens were isolated from wilting seedlings and trees in several Eucalyptus plantations. The phenotypic diversity analysis included biovar, exopolysaccharide quantification and virulence tests, while genotypic diversity included phylotypes and sequevar determination based on egl gene sequences. A total of 35 strains were isolated from the field and nurseries of Eucalyptus in various locations. All isolates were confirmed as Ralstonia species complex based on morphological characteristics and molecular studies using species-specific primers. These isolates were dominantly classified as biovar 3 and 4 and had a high variation on virulence and EPS production. Based on the egl sequence's alignment, 29 strains of Phylotype I are grouped into four sequevar references (sequevars $14,17,18,30$ ) and new a sequevar 58. This study shows that strains of $R$. pseudosolanacearum causing bacterial wilt on $E$. pellita in Indonesia have high phenotypic and genotypic diversities.
\end{abstract}

Keywords: Diversity, endoglucanase, exopolysaccharide, Eucalyptus pellita, species complex

\section{INTRODUCTION}

Bacterial wilt on eucalypt was first reported in China (Cao 1982) and Brazil (Sudo et al. 1983), then in Indonesia in 1985 (Machmud 1985). Subsequently, massive attacks on eucalypt plantations occurred in Australia, Venezuela, Paraguay, South Africa and Indonesia (Santiago et al. 2014; Coutinho et al. 2000; Siregar et al. 2020). The studies of the disease were mostly on Eucalyptus camaldulensis, E. dunii, E. grandis, E. urophylla, E. saligna, and their hybrids. Little research has been dedicated to bacterial wilt disease on E. pellita and its few developed hybrids, despite the importance of the species to Indonesian forestry, where losses due to outbreaks of the disease both in nurseries and plantations in 2010-2011 were estimated at IDR 16 billion (Siregar et al. 2012).

The causal agent of bacterial wilt disease on E. pellita, Ralstonia solanacearum, was further identified as race 1 biovar 3 (Siregar et al. 2012; Tjahjono et al. 2011). Carstensen et al. (2017) reported bacterial wilt disease on eucalypts in Asia and Africa as Ralstonia pseudosolanacearum (Phylotype I), which refers to changes in the nomenclature of the Ralstonia species (RS) complex (Safni et al. 2014). The diversity of phenotypic and genotypic traits of this pathogen is high enough that it is referred to as a complex species. The RS complex was initially classified into five races and five biovars (Denny and Hayward, 2001). However, this approach cannot classify isolates according to their phylogenetic history or geographic origin (Fonseca et al. 2014). Therefore, a phylotype and sequevar system was formed, considering the geographic distribution, the diversity of the endoglucanase $(e g l)$, and the hypersensitivity response and pathogenicity ( $h r p$ ) gene (Fegan and Prior, 2005). This classification can study the population of pathogens in a specific geographic area and their virulence properties.

The RS complex produces several virulence factors, including plant cell wall degrading enzymes (e.g. endoglucanase) and exopolysaccharide I (EPS); thus, the virulence of each strain is phenotypically different. Enzymes that destroy plant cell walls make a strain more virulent by increasing the invasion and colonization of vessel tissue (Saile et al. 1997), but these enzymes are unnecessary for disease development. Meanwhile, EPS is essential for the appearance of wilt symptoms and plant death (McGarvey et al. 1998). EPS is produced in excessive amounts both in vitro and in planta and is believed to function by clogging the xylem vessels causing wilting. The EPS quantification produced by pathogens is one of the indicators of pathogen's virulence in causing disease symptoms. 
Molecular methods have been used in further understanding of RS diversity (Chesneau et al. 2018; Sharma et al. 2021). Molecular identification of the causal agent of bacterial wilt on Eucalyptus in Indonesia at the phylotype and sequevar levels has not been attempted. Besides, knowledge of phenotypic diversity is also essential to see virulence level of each dominant pathogen isolate in a population. This study aims to describe diversity of the causal agent of bacterial wilt on E. pellita.

\section{MATERIALS AND METHODS}

\section{Sample collection}

Samples were taken from E. pellita seedlings and trees from nursery and field plantation areas, in Riau, Jambi, South Sumatra and East Kalimantan, Indonesia. Plants showing bacterial wilt symptoms (i.e., yellow leaves followed by wilting branches) were selected and had their stem cut transversally. A bacterial exudate coming out from the plant vessels confirmed the bacterial wilt disease. The infected tissues were then put into plastic bags, labeled, and taken to the lab.

\section{Pathogen isolation}

Pathogen isolation was carried out from wilted symptomatic Eucalyptus trees and seedlings from different locations, ages, and Eucalyptus clones following the procedure described in Tjahjono (2015). Infected stems were cut transversely and placed in a soaked container and sterilized with $5.25 \% \mathrm{NaOCl}$ twice, then rinsed with sterile water. The stem pieces were then inserted into a test tube containing $10 \mathrm{~mL}$ of sterile distilled water and stirred in an incubator shaker for $30 \mathrm{~min} .0 .1 \mathrm{~mL}$ of the solution was transferred to a Petri dish containing TZC growth medium (2,3,5-triphenyl tetrazolium chloride) and incubated at 28 ${ }^{\circ} \mathrm{C}$ for 72 hours. A single colony of virulent bacteria with irregular shape, fluid, and pink in color was taken and rejuvenated in another Petri dish containing TZC medium. Some RS isolates from chili, tomato, acacia, and ginger were used as an out-group. Confirmation of RS species complex was performed using PCR species-specific primers (explained later in a separate section).

\section{Phenotypic diversity analysis Biovar determination}

Biovar of each strain was determined using a Basal medium containing $1.0 \mathrm{~g} \mathrm{NH} 4 \mathrm{H} 2 \mathrm{PO} 4,0.2 \mathrm{~g} \mathrm{KCl}, 0.2 \mathrm{~g}$ MgSO4.7H2O, $1.0 \mathrm{~g}$ Peptone, $3.0 \mathrm{~g}$ agarose, $80 \mathrm{mg}$ bromothymol blue in $1000 \mathrm{~mL}$ distilled water (Denny and Hayward 2001). The pH was adjusted to 7.0-7.1 (green color). The medium was heated to melt the agar, poured into Erlenmeyer, and sterilized in autoclave at $121{ }^{\circ} \mathrm{C}$ for $20 \mathrm{~min}$. The $10 \%$ aqueous solutions of each different carbohydrate source (dextrose, mannitol, sorbitol, dulcitol, trehalose, lactose, maltose D (+) cellobiose) was sterilized using filter sterilization. Ten $\mathrm{mL}$ of the carbohydrate solution was added to $90 \mathrm{~mL}$ of warm basal medium to get a final concentration of $1 \%$. Once homogeneous, $3 \mathrm{~mL}$ of the molten medium was added to a sterile test tube and allowed to solidify. One hundred $\mu \mathrm{l}$ of a $48 \mathrm{~h}$ old culture of RS strains was added into the test tube and incubated at $28^{\circ} \mathrm{C}$. The test tubes were examined at $3,7,14$, and 28 days after inoculation for $\mathrm{pH}$ changes (indicated by the color change). The biovars of the RS isolates were determined as described in Denny and Hayward (2001).

\section{Exopolysaccharide (EPS) quantification}

Quantification of EPS as a virulence factor for RS bacteria was carried out following the protocol described by Peyraud et al. (2017). A total of $5 \mathrm{~mL}$ of $24-48 \mathrm{~h}$ old liquid culture of bacterial strains with a minimum concentration of $5 \times 10^{8} \mathrm{cfu} / \mathrm{mL}$ was filtered using a 0.22 $\mu \mathrm{m}$ syringe filter and the supernatant was collected on a 1.5 $\mathrm{mL}$ microcentrifuge tube. A fraction of $0.2 \mathrm{~mL}$ of the supernatant was mixed with $0.004 \mathrm{~mL}$ of $5 \mathrm{M} \mathrm{NaCl}$ and 0.8 $\mathrm{mL}$ of acetone for extraction. The solution was stirred with a vortex for $10 \mathrm{sec}$ and stored at $4{ }^{\circ} \mathrm{C}$ for 12 hours (overnight). The remaining supernatant was stored at $20^{\circ} \mathrm{C}$.

After the 12-hour-period, the suspension was centrifuged for $10 \mathrm{~min}$ at $13,000 \mathrm{rpm}$ and $4{ }^{\circ} \mathrm{C}$; the supernatant was then removed, and the pellet was air dried. The dried pellets were then dissolved with $0.2 \mathrm{~mL}$ of $\mathrm{ddH}_{2} \mathrm{O}$. The suspension can be stored at $4{ }^{\circ} \mathrm{C}$ for several days until quantification is carried out. For the EPS quantification, the suspension was heated using a dry bath heater at $65^{\circ} \mathrm{C}$ for $10 \mathrm{~min}$, then mixed with a Vortex and centrifuged for $5 \mathrm{~min}$ at $13,000 \mathrm{rpm}, 4^{\circ} \mathrm{C}$. The supernatant was transferred to a $2 \mathrm{~mL}$ microcentrifuge tube for subsequent EPS quantification.

Two hundred $\mu \mathrm{l}$ of the EPS sample was mixed with $0.15 \mathrm{~mL}$ of $\mathrm{HCl}(37 \%)$ and the volume was completed to $0.6 \mathrm{~mL}$ with $\mathrm{ddH}_{2} \mathrm{O}$ in a $2 \mathrm{~mL}$ tube. The tube was shaken with a Vortex, closed tightly and placed on a dry bath heater at $115^{\circ} \mathrm{C}$ for $30 \mathrm{~min}$. The tube was then allowed to cool down to room temperature and centrifuged for $5 \mathrm{~s}$ at $6,000 \mathrm{rpm}$. $0.4 \mathrm{~mL}$ of $2 \mathrm{M} \mathrm{Na}_{2} \mathrm{CO}_{3}$ was added slowly and mix gently. In the final step, $0.5 \mathrm{~mL}$ of $2 \%$ acetyl acetone solution in $1.5 \mathrm{M} \mathrm{Na}_{2} \mathrm{CO}_{3}$ was added into solution and the tube was vortexed. $\mathrm{CO}_{2}$ was released from the tube and the tube was kept open to avoid heating of the solution. The tube was then mixed gently once the $\mathrm{CO}_{2}$ bubble slows down and vortexed well. The tube was incubated $30 \mathrm{~min}$ in the dark condition; the level of turbidity (optical density/OD) of the solution was then read at $530 \mathrm{~nm}$. Pure water was used as a blank control. EPS quantity was calculated based on the relationship between the standard OD curve and the concentration of $\mathrm{N}$-acetylgalactosamine.

\section{Virulence test}

The virulence test was carried out through artificial inoculation of 3-month-old eucalypt seedlings in growth chamber. Inoculation was performed using the method described by Fonseca et al. (2015) with some modifications. A 3-day-old bacterial cell suspension $(0.5$ $\mathrm{mL}$ ) was injected into an artificial wound at the seedling's stem base (1 $\mathrm{mm}$ deep and $10 \mathrm{~mm}$ long using a scalpel) 5 $\mathrm{cm}$ above the ground. 
Table 1. Host resistance score category of virulence test

\begin{tabular}{llll}
\hline \multirow{2}{*}{ Score $^{+}$} & \multicolumn{3}{c}{ Sign* and Symptom $^{+}$} \\
\cline { 2 - 4 } & Ooze at $\mathbf{~ c m}$ & Ooze at 3 cm & Plant condition \\
\hline 5 & Negative & Negative & Healthy \\
4 & Negative & Positive & Healthy \\
3 & Positive & Positive & Healthy \\
2 & Positive & Positive & Wilting / died \\
1 & Negative & Positive & Wilting / died \\
\hline
\end{tabular}

Note: + A higher score indicates a higher host resistance level,

* The bacterial ooze observed (under microscope) on cut stem samples at 3 and $6 \mathrm{~cm}$ above the inoculation point

The wound was then covered using wet cotton wool and wrapped with parafilm to keep it moist and to avoid contamination by other microorganisms. Each bacterial strain was inoculated into10 plants and three other wounded plants but with no inoculum were used as control. Inoculated and control plants were incubated in growth chamber at a temperature of $28 \pm 2^{\circ} \mathrm{C}$, humidity $>80 \%$, and 12 hours of photoperiod, with light intensity of 40 $\mu \mathrm{mol} / \mathrm{s} / \mathrm{m}^{2}$. Plants' symptoms were daily evaluated to observe latent period, disease incidence, and host resistance score (Table 1) until 30 days after inoculation.

\section{Genotypic diversity analysis}

Phylotype-Specific Multiplex PCR (m-PCR) amplification

Genomic DNA was extracted using the Bacteria Genomic DNA Kit (Geneaid), according to the manufacturer's instructions. A PCR test using speciesspecific primers OLI1 and Y2 (Table 2) to amplify a 288 base pair (bp) product was performed to confirm that all isolates belong to the RS species complex. Each $25 \mu \mathrm{L}$ reaction mix contained $1 \mathrm{x}$ reaction buffer, $1 \mathrm{U}$ Taq DNApolymerase (Green GoTaq), $25 \mathrm{mM} \mathrm{MgCl}_{2}, 2.5 \mathrm{mM}$ dNTP mix, $10 \mu \mathrm{M}$ of each primer, and $20 \mathrm{ng}$ of DNA template. Amplification was carried out in a 2720 Thermal Cycler (Applied Biosystems). The reaction conditions used were heating at $94{ }^{\circ} \mathrm{C}$ for 2 min followed with 30 cycles at $94{ }^{\circ} \mathrm{C}$ for $30 \mathrm{~s}, 55{ }^{\circ} \mathrm{C}$ for $30 \mathrm{~s}, 72{ }^{\circ} \mathrm{C}$ for $1 \mathrm{~min}$, and a final extension at $72{ }^{\circ} \mathrm{C}$ for $5 \mathrm{~min}$. Water control was included in every PCR assay to confirm that there was no contamination in the assay.

The mPCR developed by Fegan \& Prior (2005) was used to classify the bacterial isolates into phylotypes using a set of four primers for each specific phylotype (Table 2).
Each $25 \mu \mathrm{L}$ reaction mixture contained $1 \times$ reaction buffer, $1 \mathrm{U}$ Taq DNA-polymerase (Green GoTaq), $25 \mathrm{mM} \mathrm{MgCl}_{2}$, $2.5 \mathrm{mM}$ dNTP mix, $10 \mu \mathrm{M}$ of each primer and $20 \mathrm{ng}$ of DNA template. Amplification was carried out in a 2720 Thermal Cycler (Applied Biosystems). The reaction conditions used were heating at $96{ }^{\circ} \mathrm{C}$ for $3 \mathrm{~min}$ followed with 30 cycles at $94{ }^{\circ} \mathrm{C}$ for $30 \mathrm{~s}, 59{ }^{\circ} \mathrm{C}$ for $30 \mathrm{~s}, 72{ }^{\circ} \mathrm{C}$ for $1.5 \mathrm{~min}$ and a final extension at $72{ }^{\circ} \mathrm{C}$ for $10 \mathrm{~min}$. The $144-$ ; 372-; 91-; and 213-bp products generated by m-PCR amplification belong to phylotypes I, II, III and IV, respectively (Fegan \& Prior 2005).

Five $\mu 1$ of the amplified product was separated on a 1.5 $\%(w / v)$ agarose gel in Tris-acetate-EDTA (TAE) buffer, stained with $0.5 \mu \mathrm{g} / \mathrm{ml}$ of ethidium bromide for $20 \mathrm{~min}$ at $60 \mathrm{~V}$ constant voltage and the gel was photographed under ultraviolet light using Alfa imager Gel Doc system. For each gel, a 100 bp DNA ladder (Promega) was used as marker to determine the amplicons' size.

\section{Partial sequencing of the endoglucanase (egl) genes}

Partial sequencing of the $e g l$ gene region was performed to identify sequevar groups (Fegan and Prior, 2005). The egl gene region was amplified using Endo-F and ENDO-R primers (Table 2). The reaction composition and PCR process conditions followed the method described by Fonseca et al. (2014). Each $25 \mu \mathrm{L}$ reaction mix contained $1 \mathrm{x}$ reaction buffer, $1 \mathrm{U}$ Taq DNA polymerase (Green GoTaq), $25 \mathrm{mM} \mathrm{MgCl2}, 2.5 \mathrm{mM}$ dNTP mix, 10 $\mu \mathrm{M}$ of each primer and $20 \mathrm{ng}$ of DNA template. Amplification was carried out in a 2720 Thermal Cycler (Applied Biosystems). The reaction conditions used were heating at $96^{\circ} \mathrm{C}$ for $9 \mathrm{~min}$ followed with 30 cycles $94^{\circ} \mathrm{C}$ for $60 \mathrm{~s}, 70^{\circ} \mathrm{C}$ for $60 \mathrm{~s}, 72^{\circ} \mathrm{C}$ for $120 \mathrm{~s}$, and a final extension at $72^{\circ} \mathrm{C}$ for $10 \mathrm{~min}$. The PCR products were purified and sequenced by Macrogen, Inc.

\section{Sequence analysis}

Phylogenetic analysis was carried out on $33 \mathrm{egl}$ gene sequences. The sequences were edited using BIOEDIT v.7.2.5 sequence alignment editor and aligned using MEGA version 10 . The phylogenetic tree was generated using the neighbor-joining (NJ) method analysis with bootstrapping 1000 replications using MEGA version 8 . All the $e g l$ sequences from the RS strains used in this study were deposited into GenBank (Table 3).

Table 2. Primers used in this study

\begin{tabular}{llllc}
\hline \multicolumn{1}{c}{ Level } & \multicolumn{1}{c}{ Primers } & \multicolumn{1}{c}{ Sequence } & Target & Reference \\
\hline R. solanacearum & OLI1 & 5'-GGGGGTAGCTTGCTACCTGCC-3' & 16s rDNA & Seal et al. 1993 \\
complex & Y2 & 5'-CCCACTGCTGCCTCCCGTAGGAGT-3' & & \\
Phylotype & Nmult: $21: 1 \mathrm{~F}$ & 5'-CGTTGATGAGGCGCGCAATTT-3' & ITS region & Fegan dan Prior 2005 \\
& Nmult: $21: 2 \mathrm{~F}$ & 5'-AAGTTATGGACGGTGGAAGTC-3' & & \\
& Nmult: $22:$ Inf & 5'-ATTGCCAAGACGAGAGAAGTA-3' & & \\
& Nmult: $23:$ AF & 5'-ATTACGAGAGCAATCGAAAGATT-3' & & Ji et al. 2007 \\
Smult: 22:RR & 5'-TCGCTTGACCCTATAACGAGTA-3' & egl gene & \\
& ENDO-F & 5'-ATGCATGCCGCTGGTCGCCGC-3' & & \\
\hline
\end{tabular}




\section{RESULTS AND DISCUSSION}

\section{Confirmation of $\boldsymbol{R}$. solanacearum species complex isolates}

A total of 39 strains were isolated from wilting eucalypt plants in plantations and nurseries in various locations (Table 3). Morphological observations of the colonies on semi-selective media and molecular observations using specific primers of RS species complex were carried out to confirm the strains. On TZC medium the virulent RS bacteria strains were round, irregular, fluidal, and pink in color, surrounded by a white fluid. As a comparison, RS strains were isolated from tomato, chilli, acacia (Acacia crassicarpa), and ginger, which showed similarity to the strains isolated from eucalypts. PCR assays with OLI1 and Y2 specific primers confirmed a positive result with the expected 288-bp-long fragments (Figure 1). All isolates tested in this study were molecularly confirmed to belong to the Ralstonia species complex and were therefore used for further tests.

\section{Phenotypic diversity of $\boldsymbol{R}$. solanacearum Biovar variability}

Twenty-seven out of the 39 tested strains utilized D(+)-cellobiose, dulcitol, lactose, maltose, mannitol, and sorbitol and thus are classified as biovar 3, while 12 strains utilized dulcitol, mannitol, and sorbitol, but not D-(+)cellobiose, lactose, and maltose and thus are classified as biovar 4 (Table 3). There were no other biovars identified.

\section{EPS quantification}

The EPS production varied from 0.13 to $8.38 \mu \mathrm{g} / \mathrm{mL}$ across the 39 strains used in this study (Table 4). This variation might be related to the virulence or latency period of wilt symptoms in the host plant.

\section{Virulence diversity of $R$. solanacearum}

Virulence differentiation of RS strains from E. pellita in a 3-month-old susceptible clone, named EP0335WK, was observed in this study. The first symptoms appeared at four days post-inoculation (dpi), on the 2 youngest leaf pairs of inoculated seedlings. The wilting started from the top leaves, then spreading down to the entire plant, followed by defoliation and plant's death. Control plants showed no visible symptoms. The latent period for each strain varied from 4 to 29 dpi.

Besides the wilting symptoms, RS-infected plants had the inner stem discolored, getting a dark brown appearance, followed by abundant secretion of bacterial ooze. A combination of wilt symptoms and the bacterial ooze secretion was used to assess the isolate's virulence and host's phenotypic response (Table 4). Host's response and disease incidence (DI) also varied in the virulence test. Twelve strains had high virulence levels (DI 80-100\%), while eight strains had low virulence levels (DI 0-25\%) at 30 dpi (Table 4).

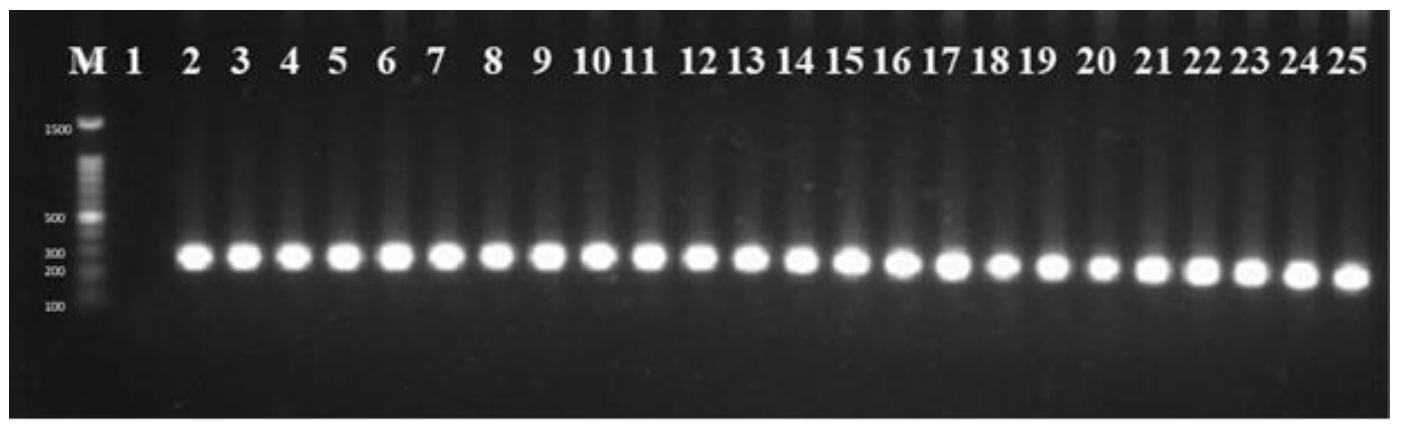

Figure 1. PCR result using OLI1/Y2 specific primers. (M) marker 100bp, (1) negative control, (2) positive control of RS, (3-22) Strains code RIE-Dr-056, RIE-Dr-067, RIE-Ge-078, RIE-Lk-014, RIE-Lk-032, RIE-Pr-051, RIE-Rd-033, RIE-Lk-047, RIE-Pr-052, RIE-Rd002, RIE-Rd-059, KTE-Sb-061P, KTE-Sb-062P, KTE-Sb-063P, JME-St-069, JME-St-071, JME-St-068, JME-St-076, JME-St-081, PBE-Me-070, respectively, (23) RIA-Mi-091 (Acacia crassicarpa), (24) YGT-Sl-099 (tomato), and (25) SBC-Ua-090 (chili).

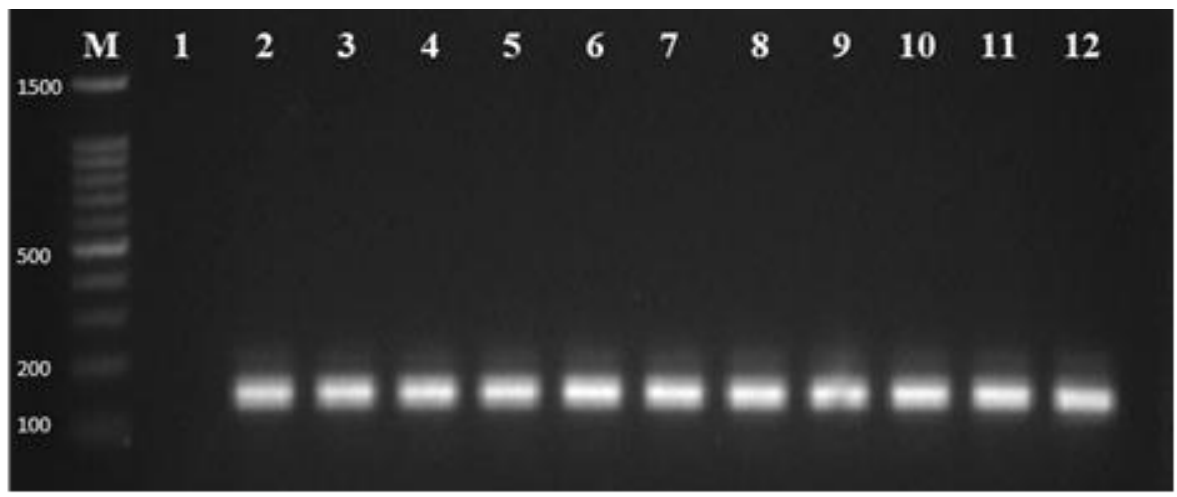

Figure 2. Multiplex PCR result with expected 144 bp specific fragments. (M) Marker 100 bp, (1) Negative control, (2-9) Strains code RIE-Dr-056, RIE-Dr-067, RIE-Lk-047, KTE-Sb-061P, KTE-Sb-063P, JME-St-069, JME-St-076, PBE-Me-070, respectively, (10) RIAMi-091 (Acacia crassicarpa), (11) YGT-Sl-099 (tomato), and (12) SBC-Ua-090 (chili). 
Table 3. List of Ralstonia strains associated with bacterial wilt of Eucalyptus pellita used for phylotyping and sequevar identification

\begin{tabular}{|c|c|c|c|c|c|}
\hline Strain code & Origin & Host & $\begin{array}{l}\text { Bio- } \\
\text { var }\end{array}$ & $\begin{array}{l}\text { Phylotype } \\
\text { / sequevar }\end{array}$ & $\begin{array}{l}\text { GenBank } \\
\text { acc. no. }\end{array}$ \\
\hline KTE-Sb-061P & East Kalimant & E. pellita & 3 & $\mathrm{I} / 18$ & MW748356 \\
\hline KTE-Sb-062P & East Kalimant & E. pellita & 3 & $\mathrm{I} / 14$ & MW748357 \\
\hline KTE-Sb-063P & East Kalimant & E. pellita & 4 & I/- & - \\
\hline KTE-Sb-102P & East Kalimant & E. pellita & 3 & $\mathrm{I} / 14$ & MW748358 \\
\hline JME-St-068 & Jambi & E. pellita & 4 & $\mathrm{I} / 18$ & MW748351 \\
\hline JME-St-069 & Jambi & E. pellita & 3 & $\mathrm{I} / 45$ & MW748352 \\
\hline JME-St-071 & Jambi & E. pellita & 3 & $\mathrm{I} / \mathrm{nd}$ & - \\
\hline JME-St-076 & Jambi & E. pellita & 4 & $\mathrm{I} / 18$ & MW748353 \\
\hline JME-St-081 & Jambi & E. pellita & 4 & $\mathrm{I} / 18$ & MW748354 \\
\hline RIE-Dr-056 & Riau & E. pellita & 3 & $\mathrm{I} / \mathrm{nd}$ & - \\
\hline RIE-Dr-067 & Riau & E. pellita & 3 & $\mathrm{I} / 45$ & MW748360 \\
\hline RIE-Ge-078 & Riau & E. pellita & 3 & $\mathrm{I} / \mathrm{nd}$ & - \\
\hline RIE-Lk-014 & Riau & E. pellita & 3 & $\mathrm{I} / 18$ & MW748361 \\
\hline RIE-Lk-032 & Riau & E. pellita & 3 & $\mathrm{I} / \mathrm{nd}$ & - \\
\hline RIE-Lk-043 & Riau & E. pellita & 3 & $\mathrm{I} / 18$ & MW748362 \\
\hline RIE-Lk-047 & Riau & E. pellita & 4 & $\mathrm{I} / 14$ & MW748363 \\
\hline RIE-Pr-013 & Riau & E. pellita & 3 & $\mathrm{I} / \mathrm{nd}$ & - \\
\hline RIE-Pr-051 & Riau & E. pellita & 3 & $\mathrm{I} / 18$ & MW748364 \\
\hline RIE-Pr-052 & Riau & E. pellita & 4 & $\mathrm{I} / 18$ & MW748365 \\
\hline RIE-Rd-002 & Riau & E. pellita & 4 & $\mathrm{I} / 18$ & MW748366 \\
\hline RIE-Rd-033 & Riau & E. pellita & 3 & $\mathrm{I} / \mathrm{nd}$ & - \\
\hline RIE-Rd-039 & Riau & E. pellita & 3 & $\mathrm{I} / 17$ & MW748367 \\
\hline RIE-Rd-040 & Riau & E. pellita & 3 & $\mathrm{I} / 17$ & MW748368 \\
\hline RIE-Rd-054 & Riau & E. pellita & 3 & $\mathrm{I} / 18$ & MW748369 \\
\hline RIE-Rd-055 & Riau & E. pellita & 3 & $\mathrm{I} / 45$ & MW748370 \\
\hline RIE-Rd-059 & Riau & E. pellita & 4 & $\mathrm{I} / 18$ & MW748371 \\
\hline RIE-Rd-093 & Riau & E. pellita & 3 & $\mathrm{I} / 45$ & MW748372 \\
\hline RIE-Rd-177B & Riau & E. pellita & 3 & $\mathrm{I} / 30$ & MW748373 \\
\hline RIE-Rs-010 & Riau & E. pellita & 4 & $\mathrm{I} / 18$ & MW748374 \\
\hline RIE-Rs-015 & Riau & E. pellita & 3 & $\mathrm{I} / 18$ & MW748375 \\
\hline RIE-Rs-016 & Riau & E. pellita & 3 & $\mathrm{I} / 14$ & MW748376 \\
\hline RIE-Rs-018 & Riau & E. pellita & 3 & $\mathrm{I} / 14$ & MW748377 \\
\hline RIE-Rs-019 & Riau & E. pellita & 3 & $\mathrm{I} / 18$ & MW748378 \\
\hline RIE-Rs-046 & Riau & E. pellita & 4 & $\mathrm{I} / \mathrm{nd}$ & - \\
\hline RIE-Rs-048P & Riau & E. pellita & 3 & $\mathrm{I} / 14$ & MW748379 \\
\hline RIE-So-017 & Riau & E. pellita & 4 & $\mathrm{I} / 14$ & MW748380 \\
\hline RIE-So-103 & Riau & E. pellita & 3 & $\mathrm{I} / \mathrm{nd}$ & - \\
\hline RIE-Tp-023P & Riau & E. pellita & 4 & $\mathrm{I} / 18$ & MW748381 \\
\hline PBE-Me-070 & South Sumatra & E. pellita & 3 & $\mathrm{I} / \mathrm{nd}$ & - \\
\hline JTT-Ml-101 & East Java & Tomato & 3 & $\mathrm{I} / 14$ & MW748355 \\
\hline RIA-Mi-091 & Riau & $\begin{array}{l}\text { A.crassic } \\
\text { arpa }\end{array}$ & 3 & $\mathrm{I} / 18$ & MW748359 \\
\hline JBJ-Bg-092 & West Java & Ginger & 4 & $\mathrm{I} / \mathrm{nd}$ & - \\
\hline SBC-Ua-090 & West Sumatra & Chili & 4 & $\mathrm{I} / \mathrm{nd}$ & - \\
\hline YGC-S1-100 & Yogyakarta & Chili & 4 & $\mathrm{I} / 14$ & MW748382 \\
\hline YGT-S1-099 & Yogyakarta & Tomato & 3 & $\mathrm{I} / 45$ & MW748383 \\
\hline
\end{tabular}

\section{Genotypic diversity}

Phylotyping and phylogenetic analysis

The mPCR results showed that all strains of RS from $E$. pellita belong to phylotype I, as seen by the expected 144 bp specific fragments (Figure 2). Based on the new classification system, phylotype I belongs to $R$. pseudosolanacearum. The same result also happened to the RS isolates from tomato, chili, ginger, and A. crassicarpa.
Thus, the $R$. pseudosolanacearum strains from E. pellita used in this study belong to phylotype I and biovar 3 or 4 .

Partial sequencing of the $e g l$ gene region was analyzed to identify sequevar groups. The $e g l$ gene sequences from the 33 strains shared $99.1 \%-100 \%$ identity. The accession numbers MW748351 to MW748383 were assigned to these sequences in GenBank. Twenty-nine strains from E. pellita and four strains from the other different hosts were used as representatives; 47 reference strains of $R$. solanacearum retrieved from GenBank were also included to construct the phylogenetic tree using the $e g l$ gene. Phylogenetic analysis of partial egl gene sequences showed that all of the 33 strains analyzed in this study were classified as phylotype I, consistent with mPCR results (Figure 3).

Table 4. Phenotypic diversity of RS strain from Eucalyptus pellita

\begin{tabular}{lllll}
\hline Strain code & $\begin{array}{l}\text { EPS quanti- } \\
\text { fication } \\
(\boldsymbol{\mu g} / \mathbf{m L})\end{array}$ & $\begin{array}{l}\text { Latent } \\
\text { period } \\
\text { (days) }\end{array}$ & $\begin{array}{l}\text { Host } \\
\text { response } \\
\text { (score) }\end{array}$ & $\begin{array}{l}\text { Disease } \\
\text { incidence } \\
(\boldsymbol{\%})\end{array}$ \\
\hline JME-St-068 & 5.88 & - & 3.6 & 0 \\
JME-St-069 & 1.60 & 5.6 & 1.4 & 100 \\
JME-St-071 & 4.70 & 20.0 & 2.4 & 60 \\
JME-St-076 & 1.10 & 3.5 & 3.5 & 50 \\
JME-St-081 & 0.40 & 14.0 & 1.8 & 100 \\
KTE-Sb-061P & 1.70 & 8.0 & 1.8 & 80 \\
KTE-Sb-062P & 4.00 & 17.0 & 3.3 & 20 \\
KTE-Sb-063P & 3.30 & 8.7 & 3.0 & 66 \\
KTE-Sb-102P & 6.30 & 23.5 & 3.5 & 40 \\
PBE-Me-070 & 4.30 & 11.5 & 2.3 & 80 \\
RIE-Dr-056 & 5.13 & 15.0 & 1.6 & 100 \\
RIE-Dr-067 & 5.13 & 10.6 & 1.6 & 100 \\
RIE-Ge-078 & 4.25 & 13.0 & 2.6 & 60 \\
RIE-Lk-014 & 5.30 & 8.4 & 1.0 & 100 \\
RIE-Lk-032 & 6.13 & 25.0 & 3.8 & 20 \\
RIE-Lk-043 & 1.70 & 16.6 & 1.3 & 100 \\
RIE-Lk-047 & 5.88 & 20.0 & 3.0 & 50 \\
RIE-Pr-013 & 2.00 & 14.0 & 3.3 & 25 \\
RIE-Pr-051 & 1.80 & 15.0 & 4.0 & 20 \\
RIE-Pr-052 & 4.88 & 18.3 & 2.8 & 50 \\
RIE-Rd-002 & 3.30 & 11.3 & 3.2 & 60 \\
RIE-Rd-033 & 0.90 & 10.0 & 2.0 & 80 \\
RIE-Rd-039 & 3.40 & 18.0 & 3.8 & 40 \\
RIE-Rd-040 & 0.40 & 16.3 & 2.3 & 66 \\
RIE-Rd-054 & 2.90 & 9.0 & 4.0 & 20 \\
RIE-Rd-055 & 0.13 & 9.8 & 2.5 & 80 \\
RIE-Rd-059 & $*$ & 6.6 & 1.7 & 100 \\
RIE-Rd-093 & 5.70 & 24.0 & 3.4 & 40 \\
RIE-Rd-177B & 0.90 & 16.8 & 2.0 & 80 \\
RIE-Rs-010 & 0.70 & - & 4.0 & 0 \\
RIE-Rs-015 & 1.10 & - & 4.2 & 0 \\
RIE-Rs-016 & 1.70 & 13.0 & 1.7 & 75 \\
RIE-Rs-018 & 3.88 & 14.0 & 2.2 & 60 \\
RIE-Rs-019 & 8.38 & 8.8 & 3.5 & 50 \\
RIE-Rs-046 & $*$ & 15.0 & 3.6 & 40 \\
RIE-Rs-048P & 2.50 & - & 4.0 & 0 \\
RIE-So-017 & 0.30 & 17.7 & 2.3 & 50 \\
RIE-Tp-023P & 5.10 & 5.7 & 2.0 & 75 \\
\hline Not: & & & \\
\hline
\end{tabular}

Note: $*$ not detected 


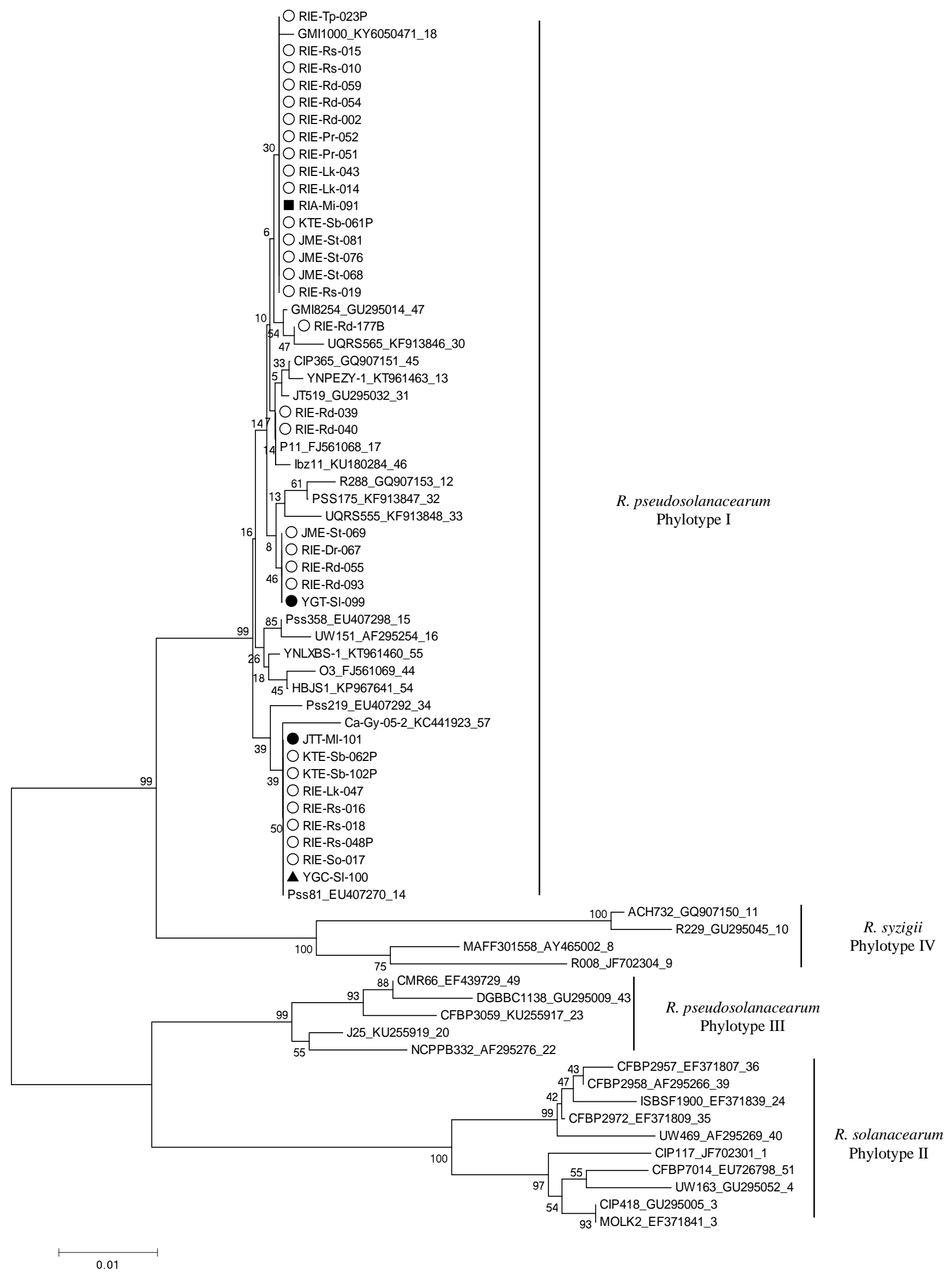

Figure 3. Phylogenetic analysis of 33 strains used in this study (white circle - from Eucalyptus pellita; black triangle - chili; black circle - tomato, black square - Acacia crassicarpa) and 49 references strains of $R$. solanacearum using the neighbor-joining method. The numbers at the tree branch points indicate the percent bootstrap support for 1,000 iterations. The name of the reference strain followed by the accession number and sequevar number 
The egl tree showed that $R$. pseudosolanacearum strains from E. pellita clustered with four major groups A, B, C, and D. Grup A, which included 15 strains, represents sequevar 18 (reference strains tomato GMI 1000). Grup B, which included seven strains, represents sequevar 14 (reference strains tomato Pss81). Grup C, which included two strains, represents sequevar 17 (reference strains peanut P11). Grup D, which only included one strain, represents sequevar 30 (reference strains ginger UQRS565). Besides, four strains from E. pellita were not identical to any previously designated sequevar, named sequevar 58. Strains from chili and tomato were grouped with sequevar 14, while strains from A. crassicarpa were grouped with sequevar 18 .

\section{Discussion}

Bacterial wilt has been reported attacking eucalypt plantations in Indonesia in the last decades (Carstensen et al. 2017; Machmud 1985; Siregar et al. 2012; Siregar et al. 2020; Tjahjono et al. 2011). The disease severity varied depending on locations, plant's age and clones. Initially, attacked plants show yellowish wilting leaves followed by wilting branches, the internal part of the stems turn blackish-brown, and bacterial exudate is seen on the cutted stems (Siregar et al. 2020). Isolation from wilting eucalypt plants from plantation and nursery resulted in 39 bacterial strains showing similar morphological characteristics such as irregular rounded shape, fluidal, and pink in color, surrounded by a white fluid on semi-selective TZC medium. The morphology of isolated colonies was consistent with previous descriptions of $R$. solanacearum (She et al. 2012). Molecularly, all isolates subjected to PCR assays with OLI1 and Y2 specific primers confirmed a positive result of the expected $288 \mathrm{bp}$ specific fragments (Seal et al. 1993). Both approaches confirm that all isolates were species from the Ralstonia complex.

The phenotypic diversity analysis of RS isolates includes biovar, exopolysaccharide quantification and virulence test. Biovar determination depends on the isolate's ability to utilize or react with certain disaccharides and hexose alcohol. Biovar 3 isolates were predominant over biovar 4 within the samples isolated from E. pellita. Previous research on the RS biovar from another eucalypt species showed that biovar $2 \mathrm{~T}$ is dominant in 'urograndis' hybrids in Brazil (Marques et al. 2012). In contrast, in Asia and Australia, biovar 3 is the most common (Coutinho et al. 2008), which is in line with results of this study. The isolates from chili and ginger were classified as biovar 4, while tomato and A. crassicarpa biovar 3. Biovars 3 and 4 found in Asia are reported to cause wilt disease in various host plants, including the Solanaceae family (Denny and Hayward 2001).

EPS is a major virulence factor of several phytopathogenic bacteria, including Ralstonia, producing high amounts of it either in pure culture or during plant multiplication (Alvarez et al. 2010). The EPS quantification is based on the determination of N-acetyl-Dgalactosamine concentration produced by isolates. In Ralstonia, it has been reported that all virulent wild-type strains produce EPS (Álvarez et al. 2010). The EPS production varied within the strains used in the present study with a value range of $0.13-8.38 \mu \mathrm{g} / \mathrm{mL}$. This number is lower than that in the previous studies, most likely because of the bacterial cell growth in minimum medium used in the studies (Addy et al. 2012, Negishi et al. 1992, Peyraud et al. 2017). Cultures grown on minimum broth medium affect the viscosity of the culture supernatant, which is most likely directly related to the amount of EPS produced by each strain (Denny et al. 1988). In plants, EPS contributes to wilting symptoms by blocking the xylem vessels, directly interfering with the movement of fluid within the plant or destroying the vessel tissue caused by excessive hydrostatic pressure. In addition, EPS plays a role in manipulating the surface structure of bacteria recognized by plant defense mechanisms; this condition causes bacteria to colonize the stems. Therefore, EPS is considered as the main virulence factor in R. solanacearum (Schell 2000; Araud-Razou et al. 1998).

The virulence test in this study succeeded in determining the virulence level of each strain. Variations in disease incidence, host response scores, and the latent period might be contributing to the varying disease symptoms incidence by each strain in plantation. The modified method developed in this study could produce disease symptoms faster than the original procedure described by Fonseca et al. (2015). This method is a breakthrough in screening for disease resistance in forest species that used to take years through old methods of observation of infected trees in plantation. This approach can be used in massive disease screening programs in growth chambers to produce superior clones as part of the plant breeding programs.

The abundance of bacterial ooze is also important to the virulence test. This ooze shows bacterial colonization in the stems and, together with EPS production, plays a role in causing wilting in plants. Virulent strains will produce symptoms with a short latent period, high incidence of disease, and low host response scores. The absence of symptoms on the susceptible clone EP0335WK inoculated with some RS strains might indicate a specific interaction between the host and certain strains. This interaction can occur by strains unable to colonization of the vessel tissue and the expression of the strains virulence factor such as EPS production and hrp gene expression in causing wilt symptoms (Zheng et al. 2017). On the other hand, plant recognizing specific signals can affect the induction of plant innate immunity (Hikichi 2016).

In this study, the RS strains obtained from E. pellita host plants and different geographical areas of four provinces in Indonesia were characterized for their phylogenetic characteristics. mPCR and phylogenetic analysis findings indicate that RS strains in Indonesia are categorized as phylotype I. This result is consistent with the current taxonomy revision, in which all strains of $R$. solanacearum from Asia are classified into Phylotype I (race 1: bv 3, 4, and 5) (Fegan and Prior 2005, Safni et al. 2014). This finding also proves earlier reports that $R$. 
pseudosolanacearum is the primary pathogen causing bacterial wilt on E. pellita in Indonesia. From $33 \mathrm{egl}$ sequences, four previously described sequevars and a new sequevar 58 were identified. Among those four sequevars, sequevar 30 has not been reported to infect Eucalyptus in Asia. Sequevar 17 and 18 have been reported on Eucalyptus in Indonesia and sequevar 14 in China (Carstensen et al. 2016). Sequevar 30 was reported in Thailand to infect ginger (Albuquerque et al. 2014). The four strains from E. pellita and one strain from tomato are proposed as sequevar 58 because it was not identical to any previous sequevar in Indonesia and Asia. Phylogenetic analysis of the egl gene sequence is in line with the phylotype result. It shows that the sequevar grouping is not limited by geographic area and host plants. It should also be noted that there is a potential for cross-infection of isolates from other plants to eucalypt plants or vice-versa.

The second-largest forest species for wood production in Indonesia after acacia species, the eucalypt faces a serious issue of bacterial wilt. This association is widely spread to eucalypt plantations throughout Indonesia. Our study shows that the use of resistant genetic plant materials and suppression of bacterial populations in the nursery environment has so far been the main control measures of the disease on eucalypt (Siregar et al. 2020). Further research should be continued to reduce the risk of losing wood yield due to this disease. In this paper, the phenotypic and genotypic properties of RS strains are shown to vary widely. This will help develop resistant clones as part of the integrated disease management.

\section{ACKNOWLEDGEMENTS}

Dissertation Grant (Beasiswa Disertasi) is supported by the Indonesia Endowment Fund for Education (LPDP), Republic of Indonesia. PT. Arara Abadi provides support and facilities for the first author to pursue the Doctoral Degree Program.

\section{REFERENCES}

Addy HS, Askora A, Kawasaki T, Fujie M, Yamada T. 2012. Loss of virulence of the phytopathogen Ralstonia solanacearum through infection by $\varphi$ RSM filamentous phages. Phytopathol 102: 469-477 DOI: 10.1094/PHYTO-11-11-0319-R.

Albuquerque GMR, Santos LA, Felix KCS, Rollemberg CL, Silva AMF, Souza EB, Cellier G, Prior P, Mariano RL. 2014. Moko diseasecausing strains of Ralstonia solanacearum from Brazil extend known diversity in paraphyletic phylotype II. Phytopathol 104: 1175-1182. DOI: 10.1094/PHYTO-12-13-0334-R.

Álvarez B, Biosca EG, López MM. 2010. On the life of Ralstonia solanacearum, a destructive bacterial plant pathogen. In: MéndezVilas A (ed.). Current Research, Technology and Education Topics in Applied Microbiology and Microbial Biotechnology. Formatex Research Center, Badajoz, Spain.

Araud-Razou I, Vasse J, Montrozier H, Etchebar C, Trigalet A. 1998 Detection and visualization of the major acidic exopolysaccharide of Ralstonia solanacearum and its role in tomato root infection and vascular colonization. Eur J Plant Pathol 104 (8): 795-809. DOI: 10.1023/A:1008690712318.

Cao JD. 1982. Investigation of bacterial wilt in E. saligna and E. grandis introduced from Brazil. Guangxi For Sci Technol 4: 30-31. DOI: 10.1111/ppa.12577.
Carstensen G, Venter S, Chen S, Wingfield M, Coutinho T. 2017. Two Ralstonia species associated with bacterial wilt of Eucalyptus. Plant Pathol 66: 393-403. DOI: 10.1111/ppa.12577.

Chesneau T, Maignien G, Boyer C, Chéron J-J, Roux-Cuvelier M, Vanhuffel L, Poussier S, Prior P. 2018. Sequevar diversity and virulence of Ralstonia solanacearum phylotype I on Mayotte Island (Indian Ocean). Front. Plant Sci 8: $2209 . \quad$ DOI: 10.3389/fpls.2017.02209.

Coutinho T, Jolanda R, Karl-Heinz R, Terblanche J. Wingfield M. 2008. First report of bacterial wilt caused by Ralstonia solanacearum on eucalypts in South Africa. Forest Pathol 30: 205-210 DOI: 10.1046/j.1439-0329.2000.00205.x.

Coutinho TA, Roux J, Riedel K, Terblanche J, Wingfield MJ. 2000. First report of bacterial wilt caused by Ralstonia solanacearum on eucalypts in South Africa. Forest Pathol 30: 205-210. DOI: 10.1046/j.1439-0329.2000.00205.x.

Denny TP, Hayward AC. 2001. Gram-negative bacteria Ralstonia. In: Schaad NW, Jones JB. Chun W (eds) Laboratory Guide for Identification of Plant Pathogenic Bacteria, 3rd ed. APS Press, St. Paul, MN.

Denny TP, Makini FW, Brumbley SM. 1988. Characterization of Pseudomonas solanacearum Tn5 mutants deficient in extracellular polysaccharide. Mol Plant-Microbe Interact 1: 215-223. DOI: 10.1094/MPMI-1-215.

Fegan M, Prior P. 2005. How complex is the Ralstonia solanacearum species complex? In: Allen C, Prior P, Hayward AC (eds) Bacterial Wilt Disease and The Ralstonia solanacearum Species Complex. Amer Phytopathological Society, St. Paul, MN.

Fonseca NR, Guimarães LMS, Hermenegildo PS, Teixeira RU, Lopes CA, Alfenas AC, 2014. Molecular characterization of Ralstonia solanacearum infecting Eucalyptus spp. in Brazil. Forest Pathol 44: 107-16. DOI: 10.1111/efp.12073.

Fonseca NR, Oliveira LSS, Guimarães LMS, Teixeira RU, Lopes CA, Alfenas AC. 2015. An efficient inoculation method of Ralstonia solanacearum to test wilt resistance in Eucalyptus spp. Trop Plant Pathol 41: 42-47. DOI : 10.1007/s40858-015-0056-2.

Hikichi, Y. 2016. Interactions between plant pathogenic bacteria and host plants during the establishment of susceptibility. J Gen Plant Pathol 82: 326-331. DOI: 10.1007/s10327-016-0680-9.

Ji P, Allen C, Sanchez-Perez A, Yao J, Elphinstone JG, Jones JB, Momol MT. 2007. New diversity of Ralstonia solanacearum strains associated with vegetable and ornamental crops in Florida. Plant Dis 91: 195-203. DOI: 10.1094/PDIS-91-2-0195.

Machmud M. 1985. Bacterial wilt in Indonesia. In: Craswell ET, Pushperajah E (eds) Bacterial Wilt Disease in Asia and The South Pacific. ACIAR, Canberra.

Marques E, Uesugi CH, Ferreira MASV, Rezende D. 2012. Characterization of isolates of Ralstonia solanacearum biovar 2, pathogenic to Eucalyptus "urograndis" hybrids. Trop Plant Pathol 37: 399-408

McGarvey JA, Bell CJ, Denny TP, Schell MA. 1998. Analysis of extracellular polysaccharide $\mathrm{I}$ in culture and in planta using immunological methods: New insights and implications. In: Prior P, Allen C, Elphinstone J (eds.). Bacterial Wilt Disease: Molecular and Ecological Aspects. Springer, New York

Negishi H, Yamada T, Shiraishi T, Oku H, Tanaka H. 1993. Pseudomonas solanacearum plasmid pJTPS1 mediates a shift from the pathogenic to nonpathogenic phenotype. Mol Plant-Microbe Interact 6: 203-209. DOI: 10.1094/MPMI-6-203.

Peyraud R, Denny TP, Genin S. 2017. Exopolysaccharide quantification for the plant pathogen Ralstonia solanacearum. Bio-protocol 7: 1-8 DOI: $10.21769 /$ BioProtoc.2289.

Safni I, Cleenwerck I, De Vos P, Fegan M, Sly L, Kappler U. 2014. Polyphasic taxonomic revision of the Ralstonia solanacearum species complex: proposal to emend the descriptions of $R$. solanacearum and $R$. syzygii and reclassify current $R$. syzygii strains as Ralstonia syzygii subsp. syzygii subsp. nov., $R$. solanacearum phylotype IV strains as Ralstonia syzygii subsp. indonesiensis subsp. nov., banana blood disease bacterium strains as Ralstonia syzygii subsp. celebesensis subsp. nov., and $R$. solanacearum phylotypes I and III strains as Ralstonia pseudosolanacearum sp. nov. Intl J Syst Evol Microbiol. 64: 3087-3103. DOI: 10.1099/ijs.0.066712-0.

Saile E, McGarvey JA, Schell MA, Denny TP. 1997. Role of extracellular polysaccharide and endoglucanase in root invasion and colonization of tomato plants by Ralstonia solanacearum. Phytopathology 87: 1264-1271. DOI: 10.1094/PHYTO.1997.87.12.1264. 
Santiago TR, Grabowski C, Mizubuti ESG, 2014. First report of bacterial wilt caused by Ralstonia solanacearum on Eucalyptus sp. in Paraguay. New Dise Rep 29: 2. DOI: 10.5197/j.20440588.2014.029.002.

Schell MA. 2000. Control of virulence and pathogenicity genes of Ralstonia solanacearum by an elaborate sensory network. Ann Rev Phytopathol 38: 263-292. DOI: 10.1094/PHYTO.1997.87.12.1264.

Seal SE, Jackson LA, Young JPW, Daniels MJ. 1993. Detection of Pseudomonas solanacearum, Pseudomonas syzygii, Pseudomonas pickettii and Blood Disease Bacterium by partial 16S rRNA sequencing: construction of oligonucleotide primers for sensitive detection by polymerase chain reaction. J Gen Microbiol 139: 1587 1594. DOI: $10.1099 / 00221287-139-7-1587$.

Sharma K, Kreuze J, Abdurahman A, Parker M, Nduwayezu A, Rukundo P. 2021. Molecular diversity and pathogenicity of Ralstonia solanacearum species complex associated with bacterial wilt of potato in Rwanda. Plant Dis 105: 770-779.

She X, Yu L, Lan G, Tang Y and He Z. 2017. Identification and genetic characterization of Ralstonia solanacearum species complex isolates from Cucurbita maxima in China. Front Plant Sci 8: 1794 DOI: 10.3389/fpls.2017.01794.
She XM, He ZF, Luo FF. 2013. Pathogen identification of Ageratum conyzoides bacterial wilt disease and its biological characteristics. Acta Phytophyl Sin 40: 533-539. DOI: 10.3389/fpls.2017.01794.

Siregar BA, Giyanto, Hidayat SH, Siregar IZ, Tjahjono B. 2020. Epidemiology of bacterial wilt disease on Eucalyptus pellita F. Muell. in Indonesia. IOP Conf Ser Earth Environ Sci 468: 012033. DOI: $10.1088 / 1755-1315 / 468 / 1 / 012033$.

Siregar BA, Indrayadi H, Mardai. 2012. Ancaman penyakit layu bakteri terhadap produktivitas Eucalyptus pellita di dataran rendah tropis. In: Plant Protection (eds) Laporan Tahunan R\&D PT. Arara Abadi. PT. Arara Abadi, Perawang, Indonesian. [Indonesian]

Sudo S, Oliveira GHN, Perreira AC. 1983. Eucalipto (Eucalyptus sp) e Bracatinga (Mimosa escabrela), novos hospedeiros de Pseudomonas solanacearum EF Smith. Fitopathol Bras 8: 631.

Tjahjono B. 2015. Isolasi dan Identifikasi Penyakit Layu Bakteri pada Eukaliptus. In: Sinarmas Forestry (eds). Instruksi Kerja R\&D PT. Arara Abadi. PT. Arara Abadi, Perawang. Indonesia. [Indonesian]

Tjahjono B, Gafur A, Golani GD. 2011. Occurrence of bacterial wilt on acacias and eucalypts in Indonesia. J ISSAAS 17 (1): 234.

Zheng X, Zhu Y, Liu B, Lin N, Zheng D. 2017. Invasive properties of Ralstonia solanacearum virulent and avirulent strains in tomato roots. $\begin{array}{llll}\text { Microbial Pathogenesis 11: 144-151. DOI: } & \end{array}$ 10.1016/j.micpath.2017.10.046. 